\section{SOI: $1.1 /$ TAS DOI: $10.15863 / \mathrm{TAS}$ International Scientific Journal Theoretical \& Applied Science}

p-ISSN: 2308-4944 (print) e-ISSN: 2409-0085 (online)

Year: $2018 \quad$ Issue: 09 Volume: 65

Published: $28.09 .2018 \quad$ http://T-Science.org
J.D. Baktiyev

aspirant of Institute of philosophy and political and legal research of National Academy of Sciences of the Kyrgyz Republic

SECTION 32. Jurisprudence.

UDC: 347.466

\title{
LEGAL STATUS OF PLEDGOR IN ACCORDANCE WITH THE LEGISLATION OF THE KYRGYZ REPUBLIC
}

\author{
Abstract: In the submitted article, the rights and obligations of pledgor shall be analyzed according to \\ legislation of the Kyrgyz Republic. Necessary amendments to normative legal acts for the purpose of securing \\ interests and rights of pledgor shall be proposed. \\ Key words: pledge, pledgor, pledge holder, immovable property, pledge agreement, legislation, rights and \\ obligations, law. \\ Language: English \\ Citation: Baktiyev JD (2018) LEGAL STATUS OF PLEDGOR IN ACCORDANCE WITH THE \\ LEGISLATION OF THE KYRGYZ REPUBLIC. ISJ Theoretical \& Applied Science, 09 (65): 224-227. \\ Soi: http://s-0-i.org/1.1/TAS-09-65-39 Doi: crossef https://dx.doi.org/10.15863/TAS.2018.09.65.39
}

\section{Introduction}

Pledge is one of the most popular ways of securing of obligations, including credit obligations in law-enforcement practice of the Kyrgyz Republic. Article 12 of the Constitution of the Kyrgyz Republic sets forth inviolability of property [1]. In civil law the way securing performance of obligations is understood as the special measures of property character provided by the legislation or the contract stimulating appropriate performance of obligations by debtors by establishment of additional guarantees of meeting claims of creditors. Therefore, G.F. Shershenevich, analyzing essence of pledge, specified that, first of all, property of debtor in structure which it has at the time of collecting provides claims of creditor [2]. However, creditor is always under the danger that property of the debtor will be lower than value of obligation, that at the same time so many claims will be imposed on property, that it won't sustain weight of its accumulation. In view of such danger, which the creditor isn't able to prevent, he prefers to choose certain property corresponding to amount of debt from all property of debtor and to get the right of exclusive satisfaction from the cost of this subject.

\section{Materials and Methods}

With development of market relations pledge as a way of securing performance of obligations, has found the broadest application at conclusion not only loan agreements, but also contract for work and labor, purchase and sale, etc. The institute of pledge exists in domestic civil law for a rather long time. However, in recent years it has experienced a peculiar rebirth.

Due to popularity, institute of pledge demands well-founded legal regulation, in particular, questions connected with rights and duties realization by the parties of pledge agreement. So, for 9 months of 2017 in comparison with the same period of 2016, number of all transactions with immovable property in Kyrgyzstan has increased, including, transactions on rent, pledge, donation and inheritance of objects of immovable property [3,4]. It causes heightened interest in consideration of legal status of persons participating in pledge legal relations.

So, who can act as pledgor under the pledge agreement? According to Art. 326 of the Civil code of the Kyrgyz Republic the pledgor can be a debtor on obligation secured with pledge, or third party who does not participate in this obligation [5]. Thus, the law defines that the identity of debtor according to main obligation and pledgor according to accessory obligation cannot coincide. However, to be fair, it should be noted, that in most cases in practice debtor and pledgor coincide in one person.

Civil code of the Kyrgyz Republic establishes that person having the property right or other real right on subject of pledge can be pledgor. At the same time, person, who possess right of economic jurisdiction or right of operational management on 
property, has right to put it in pledge with consent of its owner.

The pledgor under pledge of rights can only be person who possess the pledged right. At the same time, pledge of tenancy or other right on special property shall not be allowed without the consent of its owner except as otherwise provided by the agreement.

Thus, pledge of property can be carried out by person who has corresponding right only. In this case, it is possible to observe correlation between norms of Civil code of the Kyrgyz Republic regulating status of pledgor and provisions determining the content of limited proprietary rights. So, according to Art. 230 of Civil code of the Kyrgyz Republic, enterprise has no right to sell immovable property belonging to it on the right of economic management, to lease it, to pledge, to bring it as contribution (share) to authorized capital of business partnerships and entities, or to dispose this property otherwise without the owner's consent. Enterprise disposes other property belonging to it on the right of economic management independently, except for the cases established by the legislation.

Therefore, the provision set forth in Art. 326 of Civil code of the Kyrgyz Republic is an exception provided by the legislation concerning the disposal of movable property by enterprises owning it on the right of economic management.

Art. 6 of the Law of the Kyrgyz Republic «On pledge» (further - Law «On pledge») also defines some aspects, characteristic for legal status of pledgor, and establishes that participants of pledge relations are citizens and legal entities of the Kyrgyz Republic, foreign citizens and legal entities (including foreign banks and specialized financial credit institutions), the Kyrgyz Republic, and also the states, which possess the property right on subject of pledge [6]. It is mentioned separately in the Law «On pledge», that pledgor under the agreement on pledge of agricultural land are citizens of the Kyrgyz Republic having the property right on subject of pledge.

Also the Law on pledge, providing restrictions on pledge of separate types of property, determines additional requirements to pledgor as to person providing pledge.

So, Art. 7 of the Law «On pledge» sets forth that participant of joint shared property has the right to pledge share in general property without consent of other owners, if share of each owner is defined in right of joint ownership. Member of cooperative or other enterprises with joint ownership can pledge independently or collectively rights on enterprise, in order established by the legislation of the Kyrgyz Republic. The owner of apartment in an apartment building makes the decision on its pledge independently.
Thus, the legislator emphasizes features of legal status of pledgor depending on a transferable subject of pledge.

As for the content of legal status of pledgor, it is possible to refer to it existence of general and specific rights and duties. General rights and duties in this case concern general established order of obligations performance. First of all, this is the duty of appropriate execution of obligation, which comprises also its real execution. Also, it is possible to refer right of pledgor to demand from the opposite side execution of duties corresponding to his own obligations, to the general elements of legal status of pledgor.

As for specific rights and duties arising from pledge, they are settled both by Civil code of the Kyrgyz Republic, and by the Law of the Kyrgyz Republic «On pledge».

As a result of legislative rules analysis, we consider following special duties of pledgor:

- a duty to support pledged property in good working order and to incur expenses on maintenance and repair (ordinary and fundamental) of this property (article 12 of the «On pledge»);

- a duty to insure pledged property in its overall cost against risk of its loss and damage, and if overall cost of property exceeds size of claim secured by pledge, - for the sum not lower than the size of claim (Art. 330 of Civil code of the Kyrgyz Republic);

- in case of actual possession of subject of pledge - a duty to take measures necessary for safety of pledged property, including for its protection from encroachments and requirements from third parties, to bear risk of eventual loss or damage of pledged property;

- a duty to immediately notify pledge holder on threat of loss or damage of pledged property;

- a duty to report in writing to each subsequent pledge holder data on all existing pledges of property and also on nature and amount of securing obligations with these pledges and to pay damages caused by pledge holder due to non-execution of this duty (Art. 329 of Civil code of the Kyrgyz Republic);

It is possible to place to the rights of pledgor the following:

- right to transfer subject of pledge to subsequent pledge (if it isn't forbidden by previous pledge agreements on the same property) (Art. 329 of Civil code of the Kyrgyz Republic);

- right to check according to documents actually existence, size, state and storage conditions of pledged property held by pledge holder;

- at gross violation by pledge holder of his duties, if it creates threat of loss or damage of pledged property, right to demand early execution of 
obligation secured with pledge and/or the early termination of pledge;

- right to demand from pledge holder to pay damages caused by loss or damage of subject of pledge;

- right to set off the claim to pledge holder on compensation of losses, caused by loss or damage of subject of pledge, with repayment of obligation secured with pledge;

- right in reasonable time to restore a subject of pledge or to replace it with other equivalent property if subject of pledge was loosed or damaged either property right to it or right of its use was abated on the basis established by the law;

- right to use subject of pledge according to its nature, including to derive an profits and income, on which the pledge right also extends, except as otherwise provided by the contract and follow from the nature of pledge;

- right without consent of pledge holder, but with prior notice, to lease pledged property, to transfer it to temporary use without compensation and under the agreement with other person to grant to him the right of limited use of this property (servitude) under conditions, that term of property use doesn't exceed the term of obligation secured with pledge; the property is transferred for use for purposes corresponding to property nature except as otherwise provided by the law or pledge agreement (Art. 16 of the Law «On pledge»);

- $\quad$ right to devise pledged property.

In modern conditions legal construction of pledge agreement due to its unique nature is used in various economic models. Development of modern domestic science of civil law has to happen including at the expense of concepts formulated and approved on the basis of other legal systems. However, it is necessary to consider traditions of domestic civil law, current legislation, developed provisions of civil law and corresponding doctrinal lines [7].

Pledge generates two types of legal relationship: between pledgor and pledge holder and between pledge holder and property. On the one hand, pledge is a way of providing obligation of debtor by establishment of relative legal connection with creditor, and on another hand, there is a direct legal connection of pledge holder and property.

Pledge in national law-enforcement practice one of the most often used ways of ensuring performance of obligations. Pledge is among almost convenient and often used ways of providing. Pledge is suitable for ensuring performance of obligations of many types, including non-contractual, and various property - both movable, and immovable, and also property rights of claim (Art. 325 of Civil Code) can be a subject of pledge. In view of importance and prevalence of pledge in 2005 the special Law of the Kyrgyz Republic "On pledge" has been adopted [6]. Based on analysis of theoretical basis of authors and scientists [8,9] and also normative legal acts of Kyrgyz Republic and court practice [10], it is possible to define, that it is necessary to conduct complex analysis from position of system approach of legal nature of pledge as institute of civil law.

Existence of rights of pledge holder depends on fate of obligation provided with pledge. According to Art. 325 of Civil Code, any property, including property items and property rights (claims), behind a number of exceptions can be a subject of pledge. Art. 325 provides the following exceptions: property withdrawn from circulation, claims inseparably linked with identity of creditor. In particular, there are claims about indemnification caused to life or health, alimony claims, rights which concession is forbidden by the law. Besides, Civil Code contains provision on possibility of expansion of objects of civil rights, which can't be a pledge subject. According to subparagraph 2 of Art. 325 of Civil Code, pledge of separate types of property, in particular property of citizens on which collecting isn't allowed, can be forbidden or limited by the law. According to Art. 4 of the Law of Kyrgyz Republic "On pledge" subject of pledge can be any property, which according to legislation of Kyrgyz Republic can be disposed by the pledge holder.

In order that the contract was considered as settled, agreement on all essential terms of the contract (Art. 328 of Civil Code) should be necessary.

Essential terms of pledge agreement are the following (Art. 328 of Civil Code):

1) Any property, including property items and property rights (claims) can be a subject of pledge. There are exceptions from this rule. First, transfer of the following property to pledge isn't allowed: a) property withdrawn from circulation; b) claims inseparably linked with identity of creditor, in particular alimony claims, on indemnification, caused to life or health, and other rights which concession to other person is forbidden by the law; c) separate types of property in cases provided by the law.

Subject of pledge can be property, which is available at pledgor, and that he will get in the future. So, at receiving of credit pledge agreement of a house which will be constructed by pledgor, can be signed; apartment which will be acquired by him under contract of purchase and sale, etc. If pledge arises on the basis of law, then pledge of property items and property rights which pledgor will acquire in the future can be provided by the relevant law.

2) pledge subject assessment. Assessment is made by the agreement of parties. Pledge agreement is recognized as unconcluded if structure of pledged 


\begin{tabular}{|c|c|c|c|c|c|c|}
\hline Impact Factor: & $\begin{array}{l}\text { ISRA (India) } \\
\text { ISI (Dubai, UAE } \\
\text { GIF (Australia) } \\
\text { JIF }\end{array}$ & $\begin{array}{r}=1.344 \\
=0.829 \\
=0.564 \\
=1.500\end{array}$ & $\begin{array}{l}\text { SIS (USA) } \\
\text { PИНЦ (Russia) } \\
\text { ESJI (KZ) } \\
\text { SJIF (Morocco) }\end{array}$ & $\begin{array}{l}=0.912 \\
=0.156 \\
=4.102 \\
=2.031\end{array}$ & $\begin{array}{l}\text { ICV (Poland) } \\
\text { PIF (India) } \\
\text { IBI (India) }\end{array}$ & $\begin{array}{l}=6.630 \\
=1.940 \\
=4.260\end{array}$ \\
\hline
\end{tabular}

property isn't specified. Pledge agreement in which there is no pledge subject assessment is considered unpledged;

3) definition, which party of pledge agreement will have a pledged property;

4) essence of obligation provided with pledge. If, for example, pledge provides obligation which has arisen from contract of purchase and sale, then it is specified in pledge agreement who is seller, buyer and that is a subject of purchase and sale (which property is on sale);

5) size of claim provided with pledge. In the given example - price of subject of contract of purchase and sale. If, for example, pledge provides obligation from credit agreement, then size of credit and percent which have to be paid for credit use is specified in the contract;

6) date of performance of obligation provided with pledge. In the given examples - term of transfer of property to buyer, term of payment of purchase price - under contract of purchase and sale; term (terms) of repayment of credit and payment of percent - according to credit agreement [5].

The agreement on three last conditions at signing of pledge agreement shall not be required. Essentially, there are conditions of obligation provided with pledge and pledgor and pledge holder cannot somehow change them, add and other. However, it is necessary to define, what obligation is provided with pledge, its size and dates of performance at signing of pledge agreement. Otherwise, being separated from basis (obligation provided with pledge), it will come to that contrary to laws of logic the accessory pledge obligation will remain unsettled (pledge provides execution of unknown what).

Except mentioned, essential terms of pledge agreement are all those conditions concerning which according to statement of one of the parties the agreement has to be reached. Pledge agreement in all cases has to be signed in writing (328 Civil Code). Usually pledge agreement is made by constitution of one document signed by the parties.

\section{Conclusion}

Thus, it is visible, that rights and obligations of pledgor according to legislation on pledge form special legal status of pledgor. It is also necessary to note that law-enforcement practice forming in the Kyrgyz Republic such is that not all of pledgors manage to exercise those rights, which are provided for them by the law. As a rule, the parties foresee other provisions in pledge agreement, than established by the law, forming at the same time a figure of pledgor more vulnerable. We consider that some of mentioned above rights of pledgor should be formulated so that they couldn't be changed by agreement of parties. It will provide necessary guarantees of interests of pledgor.

\section{References:}

1. (2010) Constitution of the Kyrgyz Republic of June 27, 2010.

2. Shershenevich G. R. (1995) Textbook of Russian civil law. - M.: Spark, 1995. - 556 pages.

3. (2018) Available: http://www.tazabek.kg/news: 1411472?f=cp; (Accessed: 10.09.2018).

4. (2018) Available: http://www.gosreg.kg/analyze-rynkanedvijimosti/244-july-2018; (Accessed: 10.09.2018)

5. (1996) Civil Code of the Kyrgyz Republic, part 1 of May 8, 1996, \# 15.

6. (2005) Law of the Kyrgyz Republic «On pledge» of March 12, 2005 \# 49.
7. Meyer D.I. (1997) Russian civil law. -M., Statute. -1997.

8. Braginsky M.I. (1998) To a question of correlation of real and obligations legal relationship. International center of financial development. - 1998.

9. (2009) Civil law. Valeev D.H., Grachev V. V., Averchenko N. N., Arslanov K. M., Baygusheva Yu. V., Bychkova E. N., Ivanov N. V., Krasheninnikov E. A., Nikiforov I. V., Abramova E. N. - M.: "Velbi", 2009.

10. (2018) Available: www.sot.kg. (Accessed: 10.09.2018). 